\title{
The wandering « Leg of an Indian King ». The cultural biography of a friction idiophone now in the Pigorini Museum in Rome, Italy
}

L'errance de la «jambe d'un roi indigène ». Biographie culturelle d'un idiophone à friction aujourd'hui au musée Pigorini de Rome Las andanzas de la " pierna de un rey indígena ». La biografía cultural de un idiófono de fricción ahora en el museo Pigorini de Roma

\section{Davide Domenici}

\section{OpenEdition}

\section{Journals}

Electronic version

URL: https://journals.openedition.org/jsa/14626

DOI: 10.4000/jsa. 14626

ISSN: 1957-7842

\section{Publisher}

Société des américanistes

\section{Printed version}

Date of publication: 31 October 2016

Number of pages: 79-104

ISSN: 0037-9174

\section{Electronic reference}

Davide Domenici, "The wandering « Leg of an Indian King ». The cultural biography of a friction idiophone now in the Pigorini Museum in Rome, Italy", Journal de la Société des américanistes [Online] 102-1 | 2016, Online since 02 December 2016, connection on 03 September 2022. URL: http:// journals.openedition.org/jsa/14626 ; DOI: https://doi.org/10.4000/jsa.14626 


\title{
The wandering « Leg of an Indian King ». The cultural biography of a friction idiophone now in the Pigorini Museum in Rome, Italy
}

\author{
Davide DomenICI *
}

The article presents new data on the history of a Mesoamerican musical instrument, which is a notched human bone used as a friction idiophone, today, held at the Pigorini Museum in Rome, Italy, where it is recorded as MNPE n. 4209. The documentary data allow for the reconstruction of the instrument's cultural biography along a time span of almost five centuries. Collected in the Mixtec Kingdom of Tututepec (Oaxaca, Mexico) during the 16th century, it passed through different Italian collections before reaching its present location in Rome toward the end of the 19th century. The text also analyzes how in its long historical journey through different contexts and regimes of value, the notched bone generated diverse sets of discourses on cultural otherness. It is argued that this discursive agency of the object is due to its enduring coevalness, a quality that allows ancient objects to be always contemporary and meaningful to different cultural audiences. [Key words: omichicahuaztli, Tututepec, Flavio Chigi, Prospero Lambertini, Pigorini Museum.]

L'errance de la « jambe d'un roi indigène ». Biographie culturelle d'un idiophone à friction aujourd'hui au musée Pigorini de Rome. Cet article présente des données nouvelles sur l'histoire d'un instrument de musique mésoaméricain, un fémur humain à encoches, utilisé comme idiophone à friction, aujourd'hui conservé au musée Pigorini de Rome, sous le numéro d'inventaire MNPE n. 4029. Les données recueillies permettent de reconstituer la biographie culturelle de cet instrument sur près de cinq siècles. Cet objet fut collecté au Xvi ${ }^{\mathrm{e}}$ siècle dans le royaume mixtèque de Tututepec (Oaxaca, Mexico), et il est passé ensuite dans plusieurs collections italiennes avant d'atteindre l'endroit où il se trouve, à Rome, vers la fin du XIX ${ }^{\mathrm{e}}$ siècle. L'article analyse également comment, au cours de son long voyage à travers différentes situations historiques et avec des régimes de valeur changeants, cet instrument de musique n'a cessé de susciter le développement de discours divers sur l'altérité culturelle. On avance aussi ici que l'agentivité discursive de l'objet est liée à sa « contemporanéité durable » (enduring coevalness), une qualité qui permet à des objets anciens de demeurer significatifs et actuels pour différents publics. [Mots-clés : omichicahuaztli, Tututepec, Flavio Chigi, Prospero Lambertini, musée Pigorini.]

* Department of History and Cultures, University of Bologna [davide.domenici@unibo.it]. 
Las andanzas de la "pierna de un rey indígena ». La biografía cultural de un idiófono de fricción ahora en el museo Pigorini de Roma. Este trabajo presenta nuevos datos sobre la historia de un instrumento musical mesoamericano, un idiófono de fricción, hecho en un fémur humano, hoy conservado en el museo Pigorini de Roma, donde se registra con el número de inventario MNPE n. 4209. Los datos recopilados permiten reconstituir la biografía cultural del instrumento a lo largo de un lapso de casi cinco siglos. Obtenido en el reino mixteco de Tututepec (Oaxaca, México) en el siglo XVI, el instrumento ha pasado a través de varias colecciones italianas antes de llegar a su presente lugar en Roma hacia el final del siglo XIX. El texto investiga también cómo en el transcurso de su largo viaje a través de diferentes contextos históricos y regímenes de valores, el hueso trabajado continuó estimulando una serie de discursos sobre la alteridad cultural. Proponemos además que la agencia del objeto se debe a su « contemporaneidad perdurable » (enduring coevalness), una cualidad que permite a los objetos antiguos de ser vistos siempre como contemporáneos y significativos aun frente a contextos culturales cambiantes. [Palabras clave: omichicahuaztli, Tututepec, Flavio Chigi, Prospero Lambertini, Museo Pigorini.]

The Museo Nazionale Preistorico Etnografico «Luigi Pigorini » (Rome, Italy) holds one of the most famous ancient Mesoamerican musical instruments. Inventoried as MNPE n. 4209, it is a friction idiophone made out of a notched human femur, of the kind known in Náhuatl as omichicahuaztli. New historical research, carried out as part of a multidisciplinary research project and presented herein for the first time, sheds light on the five centuries-long cultural biography of the musical instrument. In the first paragraphs of the article, besides briefly presenting the instrument and its classification according to emic Mesoamerican categories, I resume what was previously known of its history. Then, I present new data in order to trace the instrument's history backward in time, until its 16th-century origin in the Mixtec kingdom of Tututepec. The text goes on retracing the cultural biography of the instrument, from the 16th century up to our days, focusing on the different ways in which the object was displayed and described. Building on the works of authors such as Fabian (1983), Appadurai (1986), Kopytoff (1986), and Thomas (1991), I stress how the object, passing through different collections, historical contexts, and regimes of value during its long cultural biography, elicited and continues to elicit different discourses on cultural otherness. I propose that this capability to produce ever-changing meanings and discourses is related to its enduring coevalness, a quality that allows ancient objects not to be relegated in the past but, much to the contrary, to pass through different epochs and cultural contexts, being always contemporary and meaningful.

The friction idiophone today recorded as MNPE n. 4290 is a part of a human left femur pertaining to an adult male. The entire distal epiphysis of the femur was removed and nineteen transverse notches were cut on the front femoral 
surface, four of them deep enough to reach the medullary cavity. The femoral head is covered by a resin that once held the tesserae of a shell (Spondylus sp.) and obsidian mosaic; today, only small fragments of some tesserae are still in place, with the impressions of the lost tesserae clearly visible on the resin's surface. Despite the removal of the distal epiphysis, the covering of the femoral head with resin, and the intense wear traces covering much of the surface, some diagnostic perimortem cut marks have been observed, suggesting that the bone had been defleshed shortly after the individual's death. The femur is associated with a cut and perforated Oliva sp. shell, which was rasped on the notches in order to produce a sound ${ }^{1}$. The high polishing of the bone surface, as well as evident wear traces both on the bone and on the shell, show that the instrument has been intensely played in the past ${ }^{2}$.

The remains of the mosaic and the presence of the original Oliva shell, which for centuries has been attached to the bone by means of a European metal chain (see below), make the MNPE n. 4209 unique among the many bone friction idiophones known today. Moreover, its uniqueness is further enhanced by its historical pedigree: in fact, even before the discovery of the new data presented below, the mention of the musical instrument in a 1745 manuscript made it the earliest documented bone idiophone to be found in a modern collection.

The Náhuatl name omichicahuaztli, loosely translatable as « bone strengthgiver » (from omitl, " bone », and chicahua, " to become strong »; see Seler 1898; Siméon 2006 [1885], p. 94, 356), shows that these kinds of instruments were perceived as members of the wider emic organologic category of the chicahuaztli, including various and diverse instruments - at least according to Western organologic categories - played during several ritual performances. In his Crónica Mexicana (1598), Hernando Alvarado Tezozomoc recorded that the Mexica played deer-bone omichicahuaztli in commemorative rituals for the dead warriors (Alvarado Tezozomoc 1878, p. 301). Nevertheless, ethnohistorical information and archaeological findings indicate that similar friction idiophones made out of human bones were produced over a long time span and in different Mesoamerican regions, suggesting that they were played in diverse ritual contexts, mostly - but not exclusively - associated with war and sacrifice, funerals, and ancestor veneration ${ }^{3}$.

1. The pairing of notched bones and shells in ancient Mesoamerica is also witnessed by several miniature representations made out of stone, like those found in offerings associated to the Great Temple at Mexico-Tenochtitlan.

2. For further information on the bioanthropological and taphonomical analyses of the object, see Bellomia et al. 2016; for the description and identification of the malacological materials, see Velázquez Castro et al. 2014.

3. On Mesoamerican bone friction idiophones, see Lumholtz and Hrdlicka 1898; Seler 1992 [1898]; Starr 1899; Beyer 1934; 1969a [1914]; 1969b [1916]; von Winning 1959; Gutiérrez Solana 1983; Lagunas 2004; McVicker 2005; Pereira 2005; Higelin Ponce de León 2012; 
In 2013, together with Valeria Bellomia and the staff of the Pigorini Museum's Scientific Laboratories, we started a multidisciplinary research project aimed at studying various aspects of MNPE n. 4209 by means of bioanthropological and taphonomic analyses, chemical characterization of constituent materials, taxonomic shell identification, and documental research on the instrument's history ${ }^{4}$. Having been in charge of this last facet of the project, I will present herein the results of my research, starting with a synthesis of what was previously known about the Italian history of the musical instrument and then pushing its historical record further back in time.

The friction idiophone today recorded as MNPE n. 4209 entered the Pigorini Museum during April 1878, together with a set of Mesoamerican objects including a mosaic-encrusted wooden mask, two mosaic-encrusted sculptural knife handles, and a carved and gilded dart thrower. The paleoethnologist Luigi Pigorini, who was collecting materials for his new museum in Rome, obtained the objects through an exchange with the Museo delle Antichità della Regia Università di Bologna.

As shown by the color plate in Luigi Pigorini's 1885 article, when the instrument entered the Pigorini Museum the Oliva shell was attached to it by means of a metal chain, also appearing in Marshall Saville's work (1922). The chain, once inserted in a hole drilled near the distal end of the femur and in a linear notch cut through the shell, was subsequently lost, arguably during one of the renewals of the museum displays during the second half of the 20th century. In his article, Pigorini stated that no information on the instrument's history was then available and also noted a fragment of a 17 th century worn paper label attached to the femur, where the Latin word Regis was barely readable, as it is today. Building his hypothesis on the works of Biart, Torquemada, and López de Gómara, Pigorini suggested that the instrument was played at the court of the Aztec emperor Moctezuma, an idea that in his opinion was strengthened by the Regis word (Pigorini 1885, p. 8-9).

Before its transfer to Rome, the musical instrument belonged to the Museo delle Antichità della Regia Università di Bologna at Palazzo Poggi, where it was held in the Museum's Room VI together with the other Mesoamerican objects and some Oriental items. Filippo Schiassi, describing in 1814 the content of

2013; Higelin Ponce de León and Sánchez Santiago 2014; Bellomia 2013; Sánchez Santiago and Higelin Ponce de León 2014.

4. Valeria Bellomia, Luca Bondioli, Alessandra Sperduti, Ivana Fiore, and Anotnio Tagliacozzo carried out the bioanthropological and taphonomic analyses; Kirsten Boss and Cosimo Potsh made DNA analyses; Adrián Velázquez Castro, Belém Zúñiga Arellano, and Norma Valentín Maldonado worked at the shell identification; Alessandra Pecci was in charge of the chemical identification of the mosaic's resin; Davide Domenici carried out the archival research on the history of the object. Some of the project's results have been presented in Velázquez Castro et al. 2014; Bellomia et al. 2016. 
the room's Closet 4, mentioned a musical instrument, « made out of a human tibia with holes, and notches similar to teeth, attached by means of a metal chain to a shell used to produce, scratching it on those teeth, a certain sound »

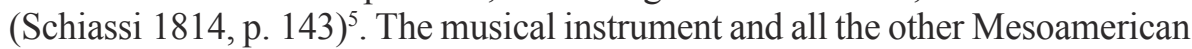
objects had actually entered Palazzo Poggi well before the foundation of the Museo delle Antichità, since the museum absorbed the content of the Stanza delle Antichità of the local Istituto delle Scienze ${ }^{6}$.

The mosaic mask, the knife handles, and the gilded dart thrower had entered the Stanza delle Antichità - together with Codex Cospi (or Codex Tlamanalli) between 1742-1743 and 1749, when it absorbed the famous Bolognese collections of Ulisse Aldrovandi and Ferdinando Cospi. Recent studies suggest that the Dominican friar Domingo de Betanzos could have brought all these items to Bologna in $1533^{7}$. On the other hand, the notched femur and the associated shell had a clearly different provenance. In fact, as noted by both Laura Laurencich Minelli (1992) and Massimo Medica (1992), a manuscript note dated April 10, 1745, held today at the Archivio di Stato in Bologna, records the instrument as part of a donation by Pope Benedict XIV - the Bolognese Prospero Lambertini - to the Instituto delle Scienze. The document, titled Nota di diversi capi spettanti ad Artefatti antichi e moderni mandati in dono dalla Santità di Nostro Signore Papa Benedetto XIV all'Instituto delle Scienze da collocarsi per ordine dell 'Illustrissima presso questa Assunteria del medesimo Instituto nella stanza delle Antichità di esso instituto, contains entries describing the bestowed objects. On folio 2, one can read « The bone of a human tibia with holes, as for playing it as a flute, with a porcelain shell attached by means of a metal chain $»^{8}$. The bottom of the anonymous document is signed - with a different handwriting - by Alessandro Branchetta, librarian of the Istituto, recording the objects' reception. It is worth noting that the document

5. "[...] formato d'una tibia umana con fori, e tagli a guisa di denti, attaccattavi mediante una catena di metallo una conchiglia da trarne, stropicciandola sopra que' denti, un certo suono ».

6. When in 1751 Gaetano Bolletti described the collection of the Istituto delle Scienze, he mentioned some Amazonian objects, but unfortunately made no mention of the bone idiophone, since he just vaguely alluded to the items housed in the Stanza delle Antichità (Bolletti 1751). Similarly, the musical instrument does not appear in Giuseppe Angellelli's 1780 re-edition of Bolletti's guide; arguably, it was included among the « many other minor things " (Angelelli 1780, p. 100).

7. See Domenici and Laurencich 2014 for an analysis of Betanzos' gift, as well as for further information on the subsequent history of the objects he brought both in Bologna and Rome.

8. " L'osso di una tibia umana con fori, come per sonarlo a guisa di flauto attacatavi, mediante una catena di metallo, una conca venerea. " Archivio di Stato di Bologna, Assunteria d'Istituto, Diversorum, B. 13, n. 5. "Conca » or " concha venerea » is a term commonly used during the 18th century to refer to the so-called «porcelain shells » or Cypraeidae (e.g., Lemery 1721; Brückmann 1722; Adanson 1757); both « venerea » and " porcelain » refer to the shape of the shell resembling a vagina. 
records the presence of the metal chain and wrongly states that it was played as a flute. Moreover, the presence of the word «tibia » suggests that the later misidentification by Schiassi derived from his reading of this document. The donation of the musical instrument by Pope Benedict XIV is not surprising, since the Bolognese Pope had been an important benefactor to the Institute, also bestowing in 1751 a second donation of mainly Amazonian objects, today split between the Museo Medievale di Bologna and the Pigorini Museum (Bolletti 1751, p. 114-115; Laurencich Minelli 1992, p. 13-14; Medica 1992).

The information summarized above was available when I started my research, trying to understand how the instrument had arrived in the hands of Prospero Lambertini. A first, useful hint derives from a clear difference between the two lots of artifacts bestowed by Lambertini to the Istituto delle Scienze. The lot given in 1751 included only Amazonian ethnographic objects that were arguably obtained by the Pope as a unitary group, maybe from a Jesuit mission in the Amazonian region (Medica 1992, p. 39) or from some other unknown source. On the other hand, the friction idiophone was probably the only American object in the previous 1745 gift $^{9}$, composed by an array of items such as Etruscan pottery, a serpentine vase, a lock, a clock, two wind musical instruments, some Chinese objects, a « wooden clog to walk on ice », etc. Such a diverse group of objects calls to mind the heterogeneity of Late Renaissance and Baroque exotica collections.

Building on this hypothesis, I searched Prospero Lambertini's private letters, looking for information regarding the origin of the 1745 lot. I found three different mentions of the 1745 gift in the correspondence addressed to Filippo Maria Mazzi, then agent of the Lambertini family in Bologna ${ }^{10}$. A letter dated April 24th, 1745, records the forthcoming shipment of the materials from Rome to Bologna, addressed to "Marquee Magnani $»{ }^{11}$. The actual shipment

9. Laurencich Minelli (1992, p. 14, n. 8) proposed to identify one of the « four pieces of different clothes, maybe of tree bark " (" quattro pezzi di panni diversi, forse di scorza d'Alberi ») with the Amazonian bark tunic today in the Pigorini Museum (n. 3317; Laurencich Minelli 1992, cat. 73). Medica tentatively identified « two oblong little gourds, painted and minutely worked » ("due zucchetti oblonghi, dipinti e lavorati minutamente ») with the two, probably Mexican excised gourds today at the Museo Medievale di Bologna (Medica 1992, p. 38; Laurencich Minelli 1992, cat. 86-78). In both cases the identifications seem debatable: in the first one, because the Pigorini tunic is rather to be identified with the « tree bark dress " ("vesta in scorza d'arboro ») mentioned in the 1751 list; in the second, because the two Mexican gourds do not show any trace of painting, thus contrasting with the gourds described in the 1745 document.

10. The manuscript letters sent by Prospero Lambertini to Filippo Maria Mazzi are today held at the Biblioteca Universitaria di Bologna. The letters are unpublished, but a useful regesto was published in 1987 (Folli Ventura and Miani 1987).

11. BUB, Ms. 4331, 2, cc. 173-174. "Nell'entrante settimana partono le stanghe di questo palazzo, che portano a Bologna una cassa per l'Istituto. Questa è diretta al Marchese 
was then recorded four days later, on April 28th ${ }^{12}$, while the arrival of the objects in Bologna is recorded in a letter dated May 22, where Benedict XIV acknowledged reception of a Mazzi's letter, dated May 13, and confirming the reception ${ }^{13}$. Two elements are worth noting here. First, what seems to be an incongruence in the timings, since the manuscript list in the Archivio di Stato di Bologna is dated April 10, that is, more than two weeks before the actual departure of the box from Rome, which occurred on Monday, April 26, 1745. Second, the mention of Marquee Magnani as the receiver of the box has been crucial to further trace the history of the object. In fact, in a letter to Magnani, dated October 28, 1744, Benedict XIV wrote: «Regarding the Institute, we are now hunting rare natural things, collected many years ago by the bright memory of the Cardinal Flavio Chigi, things that are still in that closet where he put them. The Prince Mr. Augusto bestowed them to us $»^{14}$. Similar details were then mentioned on April 14, 1745, when the Pope wrote « We are here assembling what remained of the museum bestowed to us by the Prince Chigi, composed of vases and very precious stones. We had them all cleaned, because it has probably been seventy years since anybody thought about it [...]. We put everything in an adequate box, that will be sent to You in Bologna, so that it will be put in the Institute, and we will not fail to give you notice of the time of shipment $\gg{ }^{15}$. A few days later, on April 24, 1745, the Pope added the following: " If we have time, together with this letter we will also send the note of the mentioned things that, well preserved, we are going to send to Bologna in order to put them in the Institute. The box will be addressed to you, and we

Magnani, e giunta che sarà non mancherà d'avvisarlo, o di fargliela capitare » (« Next week the Palace carriages will leave, bringing to Bologna a box for the Institute. The box will be sent to the Marquee Magnani, and when it will arrive he will give you notice or bring it to you »).

12. BUB, Ms. 4331, 2, cc. 179-180. « Sono già partite le stanghe di palazzo che portano il Baldacchino e la cassetta per l'Istituto diretta al marchese Magnani, come avvisammo colla passata, e le stanghe sono partite lunedi mattina » (" The palace carriages left, bringing the Canopy and the box for the Institute addressed to marquee Magnani, as we gave notice with the previous letter, and the carriages left on Monday morning »).

13. BUB, Ms. 4331, 2, cc. 191, 198.

14. « A proposito poi dell'Instituto, stiamo attualmente facendo una caccia di cose rare naturali, radunate tant'anni sono dalla chiara memoria del cardinale Flavio Chigi, e che sono per anche in quell'armario, in cui esso le fece porre. Il principe Don Augusto ce ne fa un regalo » (Prodi and Fattori 2011, p. 318-319).

15. « Noi qui mettiamo assieme quello che ci è restato del museo regalatoci dal Principe Chigi, che consiste in vasi e pietre molto pregiabili. Noi abbiano fatto ripulire tutto perché dovevano essere settant'anni che non vi si era pensato [...]. Il tutto si mette in una cassa proporzionata, e si manderà a Bologna diretto a Lei, acciò sia posto nell'instituto, e non lasceremo d'avvisare il tempo della partenza » (Prodi and Fattori 2011, p. 393). 
won't fail to give you notice of the shipment $»^{16}$; in the same letter, obviously written over various days, he then added « we succeeded in having the note of the abovementioned things, and it is attached herein. They advised us to send them with the palace carriages, so that they will be better protected $\rangle^{17}$. Two other letters then provide further information on the logistics of the shipment ${ }^{18}$.

Apart from the obvious matching with the information contained in the letters to Mazzi, it is worth noting here two other elements. The first, of mainly documental interest, is the mention of the « note » that Benedict stated to have attached to the April 24 letter, since it is clear that the Pope was referring to the very same manuscript note dated April 10 and today held in the Archivio di Stato in Bologna. This explains the abovementioned chronological incongruence: the Pope had the list written in Rome on April 10 and then he attached it to the April 24 letter to Magnani, who gave it to the Istituto delle Scienze together with the objects; finally, in the Institute, the Librarian Alessandro Branchetta added the last lines and his signature, presumably around May 12, 1745.

More importantly for our purposes, Benedict XIV clearly stated that some of the objects, given to him by Prince Augusto Chigi, were formerly part of Cardinal Flavio Chigi's collection, thus providing a crucial element to trace the history of the musical instrument further back in time.

Flavio Chigi I, or Seniore (1631-1693), besides being a renowned collector of Classical antiquities, had been assembling a « Museum of natural, stranger, and ancient curiosities » in the Casino alle Quattro Fontane, since 1664. Here, a first nucleus of materials formerly collected in the Palace of Formello was gradually augmented in the following years (Incisa della Rocchetta 1925; 1966; Stumpo 1980; Cacciotti 2004). The collection of the Chigi Museum was recorded in 1706 in an inventory list, including more than eight hundred items ${ }^{19}$.

16. « Se possiamo avere in tempo, manderemo annessa a questa nostra la nota delle cose già avvisate, e che ben custodite siamo in procinto di mandare a Bologna, per esser poste nell 'instituto. Sarà la cassa intestata a lei, e non lasceremo di avvisarne la partenza » (Prodi and Fattori 2011, p. 393).

17. "Ci è riuscito d'avere la nota delle robbe di sopra avvisate da riporre nell 'instituto, ed eccola annessa. Siamo stati consigliati di mandarle colle stanghe di palazzo acciò venghino meglio custodite » (Prodi and Fattori 2011, p. 397).

18. On April 28, 1745, the Pope wrote Magnani that « On Monday morning the palace carriages left, followed by a mule; and this is who carries the box, with the things for the Institute, whose copy we sent last week ("Lunedi mattina partirono le stanghe di palazzo con un mulo carico dietro; e questo è quello che porta la cassetta, ove sono le cose destinate per l'instituto, delle quali mandammo copia la settimana passata»). The arrival in Bologna of the objects was confirmed in a May 19 letter (from Castel Gandolfo), where the Pope acknowledged the reception of a Magnani's letter dated May 12 in which the Marquee had confirmed that the shipped things had arrived safely in Bologna (Prodi and Fattori 2011, p. 398, 408).

19. There are two manuscript copies of this 1706 inventory, with minor variants: one is today at the Archivio di Stato di Roma (Notai A.C. 3248. Francesco Franceschini), while 
Not surprisingly, among them there is « a bone of the leg of an Indian king transformed by his enemy in a castanet to be played in contempt for him $»^{20}$. Arguably, the 17th century-paper label mentioning a « king » was attached to the bone when it entered the Chigi collection. Even if the transfer of objects from the Chigi Museum to the Lambertini collection was already known (Incisa della Rocchetta 1966, p. 144-145; Cacciotti 2004, p. 17-18; Emiliani 2004), the Chigi origin of the Pigorini notched femur was unnoticed so far.

Notwithstanding the vague language of its entries, the reading of the 1706 inventory makes clear that the bone idiophone was not the only American item in the Chigi collection, also including at least four hammocks, a tecali (alabaster) box, the head of a Mexican magpie, a bezoar stone and, probably, some featherworks and a mosaic mask ${ }^{21}$. Flavio Chigi purchased some of these items himself, while others were shipped by his correspondents from the Americas. A hammock, for example, was bought by Chigi in Paris, when his collection was still in the Formello Palace (Cacciotti 2004, p. 8, n. 84); various other objects were shipped from New Spain to Genoa in 1666, thanks to the mediation of the Jesuit priest Athanasius Kircher $^{22}$. Nevertheless, the analysis of the documents related with these shipments, as well as a search in Kircher's epistolary exchanges with his correspondents in New Spain (Osorio Romero 1993), found no mention of the musical instrument. Unfortunately therefore, the specific details of its arrival in the Chigi collection remain unknown.

Even if we cannot know how and when Flavio Chigi received the musical instrument, another document provides interesting data regarding its possible arrival in Italy, much before its transfer to the Chigi collection. This document is a published but understudied printed booklet of eight pages, titled Descrittione dell'India occidentale chiamata il mondo novo, donde sotto brevità, Intenderai il modo de gli Idoli loro \& del lavorar la terra, cose belle e rare, Raccolte da un sacerdote che di là è venuto \& le ha portate seco alcune gentilezze fatte di mano de'detti Indiani, suttilissimamente lavorate. The booklet is anonymous

the other is held in the Chigian Archive at the Biblioteca Apostolica Vaticana. G. Incisa della Rocchetta (1966) published the complete transcription of the former, noting the variants found in the latter.

20. «[ [...] osso di gamba di re indiano convertito dal suo nemico in gnaccara da sonare per suo dispreggio » (Incisa della Rocchetta 1966, p. 174). The word " gnaccara » is an archaic and dialectal form for "nacchera ", or castanet, probably used in the inventory as a general term referring to idiophones.

21. The 1706 inventory lists various «Indian » objects but, as usual in Early Modern inventories, the term is often ambiguous, since it can refer to objects from both the East and West Indies, and even from Africa or any other exotic place (Keating and Markey 2011). The American objects of the Chigi collection will be the subject of a specific article by the author.

22. The letter mentioning this shipment, today at the Biblioteca Apostolica Vaticana (Ms. Chigiano R.V. g. [37/6]) was transcribed by Incisa della Rocchetta 1966, p. 151, n. 18. 
and undated, but its typographic traits as well as various elements of its content strongly suggest that it was printed somewhere in Italy during the 16 th century ${ }^{23}$. Building on some textual passages showing its dependence from the Italian text of the so-called Anonymous Conqueror (first published in the third volume of G. B. Ramusio's Navigationi et Viaggi, Venice 1556), as well as from the Italian edition of López de Gómara's La Conquista del Messico (Rome 1555), I propose that the Descrittione was published after 1556; the iconography and style of the initial of the text, as well as the mention of an Italian currency called bagattino, suggests that the text was printed in the third quarter of the 16th century, maybe in Venice. Moreover, the content related with missionary activity in the Mixtec and Zapotec regions of Oaxaca suggests that the missionary mentioned in the text could well be the Dominican Juan de Córdova who, between 1561 and 1564 travelled twice from New Spain to Rome in his role of definidor of the Dominican province of Santiago de México, and whose Italian voyages could be also related with the arrival of Codex Vatican A (Vat. lat. 3738) at the Biblioteca Apostolica Vaticana between 1565-1566 ${ }^{24}$. The detailed underpinning of my argument would require much more space than allotted here, so that I remit the reader to other works where various aspects of the Descrittione are more thoroughly discussed (Domenici in press $b$, in preparation).

Notwithstanding the precise dating and identification of the main character of the Descrittione, its content is relevant for the history of the notched femur. The Italian text, in fact, contains a list and a description of some Mesoamerican objects - including both « idolatrous » ones and featherworks with Christian imagery - brought to Italy by an anonymous priest who had preached among the Zapotec and Mixtec Indians. The first two items brought to Italy are listed

23. As far as I know, the only extant copy of the printed booklet was once owned by Marcel Chatillon, who, in 2003, bestowed it to the Bibliothèque Mazarine in Paris, where it is still held with the signature Ant $16^{\circ} 238$ [Res] : Chatillon. It is a printed booklet in octavo composed of four leaves continuously numbered only on the right ones (A, 2, 3, 4), bound by Marcelin Lortic (1852-1928) in red Morocco leather. The pages measure approximately $153 \times 103 \mathrm{~mm}$. The document has been so far discussed at least on three occasions. In 1979, it was presented at the Vancouver International Congress of Americanists, arguably by Chatillon himself. In 1983, P. Massajoli and M. Mattioni published the transcription of the text; despite some interesting observations, their article is plagued by erroneous cultural and linguistic interpretations, as well as by the fact that they appear to confuse the author of the text with the priest mentioned in it. Their proposal about a Venetian origin of the text is interesting, while their dating of the document around 1535 in based on wrong assumptions (Massajoli and Mattioni 1983). In 2006, Jean-Paul Duviols published a photostatic reproduction of the whole document, accompanying it with a brief commentary where he states that the document was previously unknown (thus ignoring Massajoli and Mattioni's article) and repeating the erroneous overlapping between the author and the priest whose activities are described in the text (Duviols 2006, p. 149-153).

24. For a recent synthesis of available data on the history of the Mesoamerican codices in the Biblioteca Apostolica Vaticana, see Domenici in press a. 
as « $[\ldots]$ a head of a King that was made prisoner in a war by another enemy King, then made into a drinking cup, worked with a turquoise mosaic » and « A bone of a thigh of the same King, made into an instrument to play, \& dance $»^{25}$. A few lines below, the text provides a detailed description of the two objects, worth to be repeated here in its entirety:

Of the head. It was a custom of the Indians from the provinces of Tututepeque, $\&$ the Zapotecs, \& from other provinces of the new world, that when some King or a high Lord was captured by another in war, in a solemn ceremony they sacrificed him alive in the temple, \& cutting his head they made it into a cup, worked with mosaic on the outside, and every year in that same day when they had the victory, they celebrated the triumph, \& during the ceremony the victorious King used to drink from the cup of the head of the said King. That is one of the twelve heads of Kings that the mentioned Religious man took together with the idols from the King of the province called Tututepeque, in said India of the new world.

Of the bone of the thigh of the same King. After having sacrificed that body, $\&$ made the head into a cup, with the bones of the thighs they used to make some instruments to play, $\&$ dance in the day of the triumph, \& they ate the flesh, \& they burned the entrails together with the rest in the temple. Of these bones, one has been taken pertaining to the same King of the head, by which one can see how vengeful they were ${ }^{26}$.

It is quite clear that the second listed item is a friction idiophone made out of human bone, and its description provides various important lines of evidence. A first element is that the pairing of the idiophone and the « cup » - pertaining to a same individual according to the text - raises the possibility that the mosaic-covered skull was not a drinking cup but a soundbox, or resonator, to be used with the idiophone, as suggested by other lines of evidence. Such use of a skull-soundbox is shown, for example, on Codex Vindobonensis (or Codex Yuta Tnoho) page 24, where 9 Wind is portrayed rasping a deer (?) scapula on

25. " [...] una testa d'un Re che fu fatto prigione nella guerra da un altro Re suo nimico, fatta a guisa d'una tazza da bere, lavorato di mosaico con turchine », and "Un'osso d'una coscia dell'istesso Re, fatto instrumento da sonar, \& balar » (Anonymous n. d., f. 1r).

26. "Della testa. Era usanza de gli Indiani delle provintie di Tututepeque, \& gli Zapotechi, $\&$ d'altre provintie del mondo novo, che quando alcun Re o gran Signor era fatto prigione da un altro in guerra, lo sacrificavano in una festa solenne così vivo nel tempio, \& tagliandogli la testa facevano di quella una tazza, lavorata di mosaico di fuori, et ogni anno in quello istesso giorno che si hebbe la vittoria, essi celebravano il triompho, \& il Re vincitore in quella festa beveva nella tazza della testa del detto Re. La qual è una di dodici teste di Regi che il detto Religioso tolse insieme con gli idoli al Re della provintia chiamata Tututepeque nella già detta India del mondo novo. / Dell'osso della coscia dello istesso Re. Dopo aver sacrificato quel corpo, \& fatto della testa una tazza, facevano degli ossi delle coscie certi instrumenti per sonar, \& balar nel dì del triompho, \& magnavano la carne, \& gli interiori insieme col resto abbruciavano appresso il tempio. Di questi ossi si ne ha portato uno dello istesso Re di chi era la testa, nella qual cosa si vede quanto fossero vendicativi " (Anonymous n. d., f. 1v-2r). 
a femur-like, notched idiophone resting on a human skull while singing during an ancestors-related mushroom ceremony that immediately preceded the first sunrise (Anders et al. 1992, p. 146-149; King 1994, p. 117-122). The lost skull mentioned in the Descrittione could have been similar to the mosaic-encrusted human skull found in Monte Alban Tomb 7, interpreted as a soundbox by Javier Urcid (2010, p. 140, fig. 14). Significantly, the upper part of Monte Alban's skull has been cut away, giving the object a cup-like appearance that could explain the functional attribution given in the Descrittione.

The phrasing of the Descrittione and its attribution to a « king » is especially interesting, since the phrase « a bone of the thigh of the same King, made as an instrument to play, \& dance » is similar - both in form and content - to the one of the Chigi inventory, where the instrument was described as « a bone of the leg of an Indian king transformed by his enemy in a castanet to be played in contempt for him ». Thus, even if it is impossible to state with certainty that the instrument mentioned in the Descrittione was precisely the same one that was later included in the Flavio Chigi collection, the similarity in phrasing and the common association with an Indian king strongly supports this hypothesis. As previously mentioned, it was probably in the Chigi collection that a paper label containing this kingly attribution was attached to the femur, thus suggesting that the information from the Descrittione was still known to Flavio Chigi himself.

Finally, the most important information contained in the Descrittione is the statement that both the bone and the skull «cup » were taken from the king of Tututepec, thus providing a quite precise cultural attribution. Tututepec, or Yucu Dzaa, on the Oaxaca coast, was in fact one of the most powerful Late Postclassic Mixtec kingdoms, conquered by Pedro de Alvarado in 1522 (Spores 1993; Joyce et al. 2004; Joyce and Levine 2008; Joyce et al. 2008; Joyce 2010, p. 266-270). The king of Tututepec, Coaxintecuhtli, died in 1522 after being imprisoned by Alvarado. Tututepec's throne was then taken by his son Iztaccoatzin (or Iztac Quihuantzin), himself baptized as Pedro de Alvarado, who died around 1550 (Caso 1970, I, p. 148; Berlin 1947; Roulet 2008, p. 41). After his death, his wife Ana Sosa acted as cacica until around 1564, when her son Melchior de Alvarado took her place as the Tututepec cacique (Caso and Smith 1966; Spores and Balkansky 2013, p. 188). If my dating of the Descrittione is correct, the time span of the kingdom of Iztac Quihuantzin, member of the indigenous ruling lineage but also baptized as a Christian, would be the most adequate where to temporally situate the activities of Christian missionaries that could have confiscated ancient « idols » but also obtained featherworks with Christian iconography.

Building on the information presented thus far, we can now try to sketch the cultural biography of the idiophone MNPE n. 4209, in the wake of the works of authors such as A. Appadurai (1986), I. Kopytoff (1986), and T. Bonnot (2009). In its five centuries-long history, the Mesoamerican musical instrument 
passed through various regimes of values, that is, through historical and cultural contexts characterized by highly diverse religious and epistemological frameworks. In time, European religious men, collectors, museum curators, and scholars looked with different gazes at the notched bone, a material object that was perceived as a proxy to imagine and understand its faraway, indigenous creators. This capacity of generating ever-changing interpretations, of shaping European ideas about religious and cultural otherness - in other words, its cultural agency - is a consequence of an important aspect of the object's materiality: its durability through time. Paraphrasing J. Fabian (1983), I would define this property of material objects as their enduring coevalness, that is, their capability of being always coeval with different people in different epochs. Fabian called denial of coevalness that longstanding chronopolitical stance of anthropological discourse that creates and ideologically subordinates otherness by pushing non-Western peoples (« pagans », « primitives », etc.) in different temporalities (the typological past of evolutionary anthropology, the atemporal present of functionalist anthropology, etc.), thus denying them the possibility of being coeval and to actively interact with the modern West. In Fabian's view, allochrony is a temporalizing practice that stands at the very base of anthropological chronopolitics. I would argue that we are at risk of reproducing a similar allochronical fallacy when we perceive ancient objects as only pertaining to the past, ignoring their capability of persisting and being continually meaningful through time. Studying the cultural biography of things appears then as a way to overcome allochrony and to recognize the objects' enduring coevalness as a property that makes them capable of generating diverse and ever-changing sets of discourses, meanings, and stories. Such a diachronically enduring social agency of objects blurs not only the limits between the fields of archaeology and anthropology but also those between things and persons, a much-debated theme in the anthropology of material culture (e.g., Kopytoff 1986; Miller 2005; Henare, Holbraad and Wastell 2007). This multiple blurring is embodied by the bone idiophone whose cultural biography, elucidated by new archival research, I try now to retell.

As far as we now know, the « social life » of the musical instrument started in the Mixtec Kingdom of Tututepec during the Late Postclassic period. Information provided by the Descrittione, also compatible with perimortem taphonomical evidence, suggests that it was produced with the femur of a sacrificed war captive, in order to be used together with its matching skull-soundbox during a triumphal performance involving music playing and dancing ${ }^{27}$. Our knowledge

27. The pairing of playing and dancing, explicitly mentioned in the Descrittione, is also found in entries in colonial vocabularies. In Alonso de Molina's Nahuatl vocabulary the term omichicauaçoa is translated as " tocar o tañer cierto huesso quando bailan o dançan " (Molina 2008 [1571], p. 77), a translation almost identical to the one that Juan de Córdova 
of Postclassic Mixtec bone idiophones is extremely reduced. Recent analyses of extant bone idiophones from Oaxaca showed that only one of them - engraved with an image of the god 9 Wind - probably proceeds from the Mixtec region, such instruments being much more common in Central and Western Mexico and, to a lesser extent, in the Zapotec regions of Oaxaca (Higelin Ponce de León 2013; Lagunas 2004). Nevertheless, the abovementioned image from the Mixtec Codex Vindobonensis/Yuta Tnoho, confirms the use of (deer?) bone friction idiophones by ancient Mixtecs in a mythohistorical ritual context related with dead ancestors, the foundation of kingdoms, and the birth of the First Sun. This evidence, paired with ethnohistorical information from the Nahua world, suggests that Mesoamerican bone idiophones were perceived as providers of some kind of life-force, a notion also suggested by the literal meaning of the Nahua word omichicahuaztli, or $"$ strength-giver $»^{28}$. These cross-cultural elements suggest that ancient Mixtecs probably perceived the bone musical instrument as a powerful object, imbued with a generative vital force of the kind that Mesoamericans often attributed to material objects (Houston 2014). Such a vital force would have been especially powerful in an artifact made out of a human bone, whose « seed-like » quality - a pan-Mesoamerican concept often expressed, for example, in Classic Maya iconography as well as in Nahua mythology and in the perceived affinity between marrow and semen in Nahua culture - has been demonstrated by various modern studies (López Austin 1996, I, p. 177, 190; II, p. 176; Houston et al. 2006). Life-giving force would have sprouted in the form of sound from the notched bone and its skull-soundbox when the instrument was played during a ritual performance. The pairing of a femur and a skull was probably not coincidental: the skulls of sacrificed individuals were often displayed on the tzompantli skull racks in many Mesoamerican cities while - according to ethnohistorical sources - their femurs were given to their

gave for the Zapotec term quègo xilla, "Vueso que tañian antiguamente en los bayles » (Córdova 1578, p. 415). Javier Urcid suggested to me that the use of a shell or a scapula as rasping devices, as well as the presence or absence of a skull-soundbox, could have been related to different, maybe rank-related, ritual contexts (Urcid, personal communication, December 2015). It is worth noting that, if we trust in the information recorded by the Descrittione, the use in Postclassic Tututepec of a bone idiophone made out from a sacrificed war captive's femur would contradict the hypothesis cautiously put forward by Higelin Ponce de León and Sánchez Santiago (2014), who proposed that in Oaxaca such postsacrificial ceremonies were held during the Classic period, while in the Postclassic period the bone idiophones would have been mostly made out of ancestors' bones extracted from burials.

28. Unfortunately, we do not know the Mixtec name of these instruments. The Dominican friar Juan de Córdoba, in his Vocabvlario en lengva çapoteca (1578), recorded not only the abovementioned term quego xilla ("Vueso que tañian antiguamente en los bayles »), but also quego xono, quecoxillaxone, translated as "Vueso otro assi como sierra » (Córdova 2012 [1578], fol. 415). The significance of such names is obscure, quego xilla literally meaning « river cotton » (Sánchez and Higelin 2014, p. 103). 
captors, who hung them to the house roof or to a pole in the patio (Durán 1995, I, p. 167; Sahagún 1982, II, p. 22, 57). Femurs are also represented as war trophies or parts of warriors' attires, as in the Cacaxtla murals, suggesting a close relationship between bones and sacrificed war prisoners, as also suggested by the Maya term b'aak, meaning both « prisoner » and « bone » (Fitzsimmons 2009, p. 167). Moreover, the use of femurs as items related to ancestor veneration and genealogical heritage is well attested in Zapotec Oaxaca, both by archaeological remains and iconographic evidence (Urcid 2008; Lind and Urcid 2010; Feinman et al. 2010; Higelin Ponce de León 2012). Such practices of preservation and display clearly show that skulls and femurs were perceived as the paradigmatic human bones, metonyms of the whole body, as also shown by their common pairing in Mesoamerican sacrificial imagery.

When Christian missionaries started their evangelizing efforts in indigenous communities, they perceived objects such as the omichicahuaztli as materializations of the « devilish » and idolatric native religion. The Mixtec region of the Coast, which was visited by priests during Alvarado's expedition, started being the target of Dominican missionaries in 1530. Dominican chronicles such as those by Francisco Burgoa are full of mentions of friars destroying and confiscating native idols, as well as of converted Indians voluntarily giving up their idols to the Catholic priests. Writing about the life of Juan de Córdova, Burgoa states that the Indians, learning the mysteries of the Holy Faith from his words (he was proficient in native languages), " asked the Baptism [...], abhorring their errors and giving up their idols » (Burgoa 1989 [1674], II, p. 110). The attempt at full eradication of the ancient religion also required some kind of knowledge of its tenets and practices, a need that resulted in the rich ethnographic inquiries carried out by missionaries in 16th century Mexico. The Descrittione is a good example of this kind of ethnographic knowledge ${ }^{29}$, as also underscored by the viable link it establishes between the notched bone and the postsacrificial bodily modifications of war prisoners.

The ethnographic language of the Descrittione is also full of allusions to the transition from the pre-Christian, idolatrous state of the Indians, to their postconversion, saved one. Both conditions are tangibly witnessed by the objects brought to Italy by the missionary: while the postconversion state of the Indians is evidenced - as often happens in 16th century texts - by featherworks with Christian imagery, the idolatrous one is materialized by items such as sacrificial knives and the musical instrument, coherently described with a language stressing themes such as sacrifice, vengeance, and cannibalism. Moreover, the

29. In his listing of various ethnographic issues, the Descrittione strongly reminds the account of the Anonymous Conqueror, a text that differs from all the other accounts written by soldiers precisely for its almost exclusive emphasis on ethnographic data (Domenici in press $b$, in preparation). 
taking of the idolatrous objects from the hands of the Tututepec king and their re-contextualization in a far-away, idolatry-free place like Italy (as well as in the detached space of the ethnography-laden text), was a powerful assertion of the triumph of the evangelizing efforts of the missionaries. From this perspective, the bone instrument brought to Italy was both a physical proof of Indian idolatry and of its abandonment by the now-converted Indians ${ }^{30}$. As also occurred with other Mesoamerican artifacts brought to Italy by Christian missionaries, the bone idiophone was perceived as a tangible instantiation of the colonial religious project of building a global Christian humanity (Domenici in press b).

The dense religious meanings associated to the bone instrument in the context of the Descrittione around the middle of the 16th century, seem to have been superseded when - approximately a century later - the notched femur was incorporated into the Chigi Museum. The language of the Chigi inventory is quite scant, but it is anyway significant that the bone was listed immediately after « the skin of a flayed Turk tanned as a Morlacco », suggesting that a section of the Museum was devoted to what was construed as rather gruesome and macabre exotica ${ }^{31}$. The Chigi museum hosted hundreds of objects from all over the world, aimed at showing the variety of naturalia and mirabilia of the cosmos, in a fashion that recalls the Wuderkammern and cabinets of curiosities of the time. In this context, the bodily remains of a sacrificed Indian king and of a flayed Turk seem to have materialized the most disturbing aspects of otherness, represented by two of its most quintessential manifestations at the time ${ }^{32}$. It is worth mentioning that while the Museum at the Casino delle Quattro Fontane also contained many Classical antiquities, the most outstanding Classical sculptures of the Chigi collection were housed in the Palazzo ai SS. Apostoli (Cacciotti 2004), as if the perfect harmony of Classical art shouldn't be contaminated by the aesthetically disturbing qualities of the exotica.

After the death of Flavio Chigi, part of its collection remained in a state of abandonment for various decades, as suggested by Prospero Lambertini's statement on the fact that the objects he received in 1745 hadn't been cleaned for seventy years. The bone idiophone and other objects of the Chigi collection then entered a new stage of their social life when they were bestowed to Benedict XIV, obviously as part of Augusto Chigi's political strategy aimed at consolidating, through gift-giving, the relationships between the Chigi family and

30. For a more thorough reading of the different religious discourses that can be read in between the lines of the Descrittione, see Domenici in press b.

31. B. Cacciotti, in his thorough study of the Flavio Chigi collection mentions as examples of macabre objects precisely the flayed Turk skin and the bone of the leg of an Indian King, without connecting this last item with the Pigorini notched femur (Cacciotti 2004, p. 10-11).

32. On the Turk as the embodiment of quintessential cultural otherness in modern Europe, see Borromeo (2008). 
the Pope, whose intellectual curiosity would have been well-known in Roman noble circles. Cleaned, recorded in an inventory list, and carefully stored in a box together with its fellow objects, the musical instrument started its new life with a two-week-long mule-back trip across the Appennines. Safely arriving in Bologna, the object was included in the collection of the Istituto delle Scienze, the scientific institution founded in 1714 by Luigi Ferdinando Marsili following the model of the Royal Society of London and the Académie Royale des Sciences of Paris. According to Marsili's plan, the Istituto was originally meant as a place where the scientific and experimental enquiry of the world was to be pursued. This scientific stance was further reinvigorated in the 1730s by the intervention of the Bolognese Archbishop Prospero Lambertini, influenced by enlightened ideals. The whole collection of the Institute was reorganized and augmented by the inclusion of the Aldrovandi and Cospi museums (Gualandi 1984). Their ethnographic materials - including the abovementioned Mesoamerican mask, knife handles, and dart thrower - were displayed in the Stanza delle Antichità together with Egyptian, Etruscan, Greek, and Roman objects. It is in such a context that the musical instrument found its new home, joining its " fellow » Mesoamerican items in order to represent the ways of life of past cultures. While in the Chigi Museum the bone idiophone shared its space with natural specimens and archaeological remains in a fashion typical of the cabinets of curiosities of the time, in the Istituto delle Scienze artificialia and naturalia were rigidly separated, according to the enlightened principles regarding the division of the fields of knowledge. The inclusion of the Mesoamerican exotica in a space devoted to « Antiquities » is noteworthy: it did not depend on the actual age of the specimens (most of them no more than two centuries old) but, rather, on the somehow ambiguous conceptual location of a « past » that was allochronically defined by both chronological and spatial remoteness (Fabian 1983).

The subsequent developments of the antiquities collection of the Istituto delle Scienze made that the notched bone and the other exotica had a progressively marginal role, as witnessed by the fact that the notched femur was not even mentioned in the guides written by Bolletti (1751) and Angelelli (1780). The aesthetic qualities of the Mesoamerican objects were so strikingly at odds with Neoclassical ideals that they were completely ignored by the French commissioners that, following Napoleon's taking of Bologna in 1796, selected the works of art to be shipped to France (Mazzetti 1840, p. 410-415; Gualandi 1984, p. 140). When the Istituto delle Scienze was later suppressed and its reassembled collection was transformed in the Museo delle Antichità della Regia Università di Bologna (1810), all the ethnographic materials were exhibited in Room VI, devoted to " exotic things » and somehow incongruous with the whole museographic program, now clearly centered on the idea of representing the local past of the city. When in 1870 Ariodante Fabretti was appointed to organize the new Archaeological Museum of Bologna, opened to the public 
in 1871, he even excluded all the ethnographic and medieval materials from the exhibition program (Morigi Govi 1984, p. 261).

In such an atmosphere of neglect, it was easy for Luigi Pigorini to arrange the exchange that in April 1878 deprived Bologna of its Mesoamerican items. In the new Regio Museo Nazionale Preistorico ed Etnografico di Roma - opened in 1875, which is only fourteen years after the birth of the Kingdom of Italy Pigorini wanted to create a center for the study of Italian prehistory, in harmony with the nationalistic and scientific ideals of the time. Within an evolutionary theoretical framework that inherited the allochronic stance of the Enlightenment, Italian prehistory and extra-European ethnography were paired as to suggest that they inhabited a similar typological time and that they could be studied by means of analogical comparisons. As previously noted, in his study of the Mesoamerican items, Pigorini supposed that the notched bone was played at the court of the Aztec king Moctezuma, thus privileging the « royal » aspect of the instrument as a witness of Aztec richness.

Today, the visitor of the Americas' room in the Pigorini Museum can see the musical instrument in a glass case devoted to human sacrifice and autosacrifice, together with a second notched bone from Guatemala, four Teotihuacan masks, a Colima figurine, a Veracruz « smiling face », a Maya eccentric, and the blade of an Aztec sacrificial knife. The text of a nearby panel describes the practices and meanings of human sacrifice and autosacrifice in Mesoamerica. The label of the bone friction idiophones - a single label for both instruments - merely states « Musical instruments in human bone and shell. Aztec culture (AD 13001521) ». Leaving aside the problem of cultural attribution, the absence of any historical information about the object's European trajectory contrasts with the facing glass where the masks, the knife handles, and the dart throwers are displayed with panels mentioning some steps of their European history.

The newly gathered historical information allows reconstructing the entangled cultural biography of the friction idiophone today recorded as MNPE n. 4209, from its procurement in the Mixtec kingdom of Tututepec, to its transatlantic voyage to Italy and its wanderings among some of the major collections of the country. A five-centuries-long documental record provides the musical instrument with one of the longest and most detailed historical trajectories known for Mesoamerican objects in modern collections. During its long journey, the instrument passed through various cultural milieus and regimes of value (Appadurai 1986; Thomas 1991), generating a set of diverse discourses that shed light both on the instrument itself and on the people who watched, touched, and described it. As a product of faraway peoples, the notched bone contributed to the shaping of ideas and discourses on religious and cultural otherness, as they were perceived in different times and contexts.

The status of the bone musical instrument as an idolatrous object paired with Christian ones in the Descrittione, as well as the accompanying comparison 
between Indians and Jews induced by the superposition between the cultural practices of autosacrifice and circumcision, reflect what Fabian called the Judeo-Christian vision of time, where the possibility of Salvation acts as an inclusive or incorporative device (Fabian 1983, p. 26). Through the spread of the Gospel resulting from the missionary enterprise, Indians could be immediately transformed into Christians. Allochrony can be instantly overcome: they can readily become us; their time can become our time.

The inclusion of the bone idiophone in the Chigi collection underwent a rather different discourse, driven by the eclectic curiosity typical of Early Modern collections of exotica and by a rather morbid stressing of what was construed as the most disturbing and gruesome aspects of cultural and religious otherness. In this context, otherness is something curious, wondrous, intellectually stimulating, but not to be drawn toward us: their place is not our place.

Another rather sharp turn seems to be reflected by the enlightened ideals that inspired later displays such as those of the Istituto delle Scienze, of the Regio Museo delle Antichità, and of the Pigorini Museum itself. In these cases, one can perceive the progressive entrenchment of the tenets of modern sciences: other cultures, fascinating and interesting as they can be with their lavish courtly ceremonies, became objects of scientific study, an enterprise assigned to a specific field of knowledge gradually separated from that of the natural sciences. Such a scientific ideal is underpinned by a naturalized, exclusive, and evolutionary conception of time that, according to Fabian, pushes the Others in the same typological time inhabited by European prehistoric ancestors: their time is not our time. A similar temporal distancing, reframed in more clearly evolutionary terms, was at the base of Luigi Pigorini museographic strategy, pairing and comparing European prehistory with ethnographic, extra-European cultural otherness.

Now that the evolutionary framework has been abandoned, the ethnographic objects seem to stand in a timeless present of cultural relativism (Fabian 1983, p. 38-52). But if this is true for the Africa and Oceania rooms of the Pigorini Museum, laden with mostly 19th and 20th century objects, the Americas' room, in contrast, displays mostly archaeological objects, a fact that reflects a widespread ambiguity concerning the conceptual place occupied by indigenous American antiquity, standing at the same time within the fields of archaeology and anthropology. Such paradoxical ambiguity is materialized in the label that today explains the bone idiophone: located in a supposedly ethnographic room, it only stresses that the instrument (as his archaeologically-recovered companion) is «Aztec », that it pertains to the past, and that it informs us about a cultural practice - human sacrifice - that requires a great deal of cultural relativism and of anthropological information to be understood in nonderogatory terms. It is precisely this information about the cultural meanings of human sacrifice that is provided by the nearby information panel. 
Thanks to the new research project organized by the Pigorini Museum and originally ignited by my own encounter with the musical instrument in the museum, it is hoped that in the near future a new label will make explicit to the visitor the social life and the storytelling skills that the wandering « leg of an Indian king » exhibited, and continues to exhibit through its long historical journey. *

* Manuscrit reçu en juillet 2015, accepté pour publication en février 2016.

Acknowledgments - I would like to thank Valeria Bellomia, Donatella Saviola, Luca Bondioli, and the whole staff of the Scientific Laboratories of the Pigorini Museum for contributing to the research project on MNPE n. 4209. Valeria Bellomia, Donatella Saviola, and Karin Pallaver read a draft of the present text, and provided useful suggestions. The paper greatly benefited from criticisms and comments from the referees Javier Urcid and Alexander Geurds. The responsibility of any error or misinterpretation is solely mine.

\section{References cited}

AdANSON Michel

1757, Histoire naturelle du Sénégal, J.S. Phillips, Paris.

Alvarado Tezozomoc Hernando

1878, Crónica Mexicana, Imprenta Ireneo Paz, Mexico.

Anders Ferdinand, Maarten JAnsen and Gabina Aurora Pérez JimÉnez

1992, Origenes e historia de los reyes mixtecos. Libro explicativo del llamado Códice Vindobonensis, Akademische Druck- und Verlagsanstald, Graz/Fondo de Cultura Económica, Mexico.

Angelelli Giuseppe

1780, Notizie dell'origine e progressi dell'Instituto delle scienze di Bologna e sue accademie con la descrizione di tutto cio che nel medesimo conservasi, nuovamente compilate, Istituto delle Scienze, Bologna.

AnONYMOUs

[n. d.], Descrittione dell'India occidentale chiamata il mondo novo, donde sotto brevità, Intenderai il modo de gli Idoli loro \& del lavorar la terra, cose belle e rare, Raccolte da un sacerdote che di là e venuto \& le ha portate seco alcune gentilezze fatte di mano de' detti Indiani, suttilissimamente lavorate, [s. n.], [s. 1.].

Appadurai Arjun

1986, « Introduction: commodities and the politics of value », in Arjun Appadurai (ed.), The social life of things, Cambridge University Press, Cambridge, p. 3-63.

Bellomia Valeria

2013, Analisi dei due strumenti musicali aztechi in ossa umane del Museo Nazionale Preistorico Etnografico Luigi Pigorini, M.A. thesis, University of Rome « La Sapienza », Rome.

Bellomia Valeria, Kirsten I. Boss, Ivana Fiore, Alessandra Sperduti, Antonino Tagliacozzo, Posth Bondioli and Luca Bondioli

2016, « A new look on ancient musical instruments from human bones. The Mesoamerican omichicahuaztli under the magnifying glass of Science », in preparation. 


\section{BERLIN Heinrich}

1947, Fragmentos desconocidos del Códice de Yanhuitlán y otras investigaciones Mixtecas, Antigua Libreria Robredo de José Porrúa e Hijos, Mexico.

BEYER Hermann

1934, « Mexican bone rattles », in Studies in Middle America, Tulane University of Louisiana (Middle American Research series, 5), New Orleans, p. 329-349.

1969a [1914], « Un instrumento musical de los antiguos mexicanos. El omichicahuaztli », El Mexico Antiguo, 11, p. 536-539.

1969b [1916], « Una representación auténtica del use del omichicahuaztli », El México Antiguo, 11, p. 541-545.

Bolletti Giuseppe Gaetano

1751, Dell'origine e dei progressi dell'Istituto delle Scienze di Bologna, Stamperia di Lelio dalla Volpe, Bologna.

BonNOT Thierry

2009, «L'approccio biografico alla cultura materiale », in Alvise Mattozzi, Paolo Volonté, Angelika Burtscher and Daniele Lupo (eds.), Biografie di oggetti. Storie di cose, Bruno Mondadori, Milano, p. 27-36.

Borromeo Elisabetta

2008, « Le "turc" à l'âge moderne. Itinéraire d'une image (du XVI siècle jusqu'au début du XVIII ${ }^{\mathrm{e}}$ siècle) : quelques réflexions ", in Maria Matilde Benzoni, Robert Frank and Silvia Maria Pizzetti (eds.), Images des peuples et histoire des relations internationales du xvie siècle à nos jours, Edizioni Unicopli/Publications de la Sorbonne, Milano, p. 3-14.

BRÜCKMANN Franz Ernst

1722, Relatio brevis physica de curiosissimis duabus conchis marinis quarum una vulva marina et altera concha venerea nominatur, Brunswick.

BurgoA Francisco de

1989 [1674], Geográfica Descripción de la Parte Septentrional del Polo Ártico de la América y, Nueva Iglesia de las Indias Occidentales, y Sitio Astronómico de esta Provincia de Predicadores de Antequera, valle de Oaxaca, Porrúa, Mexico.

CACсіотTI Beatrice

2004, La collezione di antichità del cardinale Flavio Chigi, Aracne, Roma.

CAso Alfonso

1970, Reyes y reinas de la mixteca, Fondo de Cultura Económica, Mexico, 2 vols.

CAso Alfonso and Mary Elizabeth Sмiтн

1966, Interpretation of the Codex Colombino/The Glosses of Codex Colombino, Sociedad Mexicana de Antropología, Mexico.

Córdova Juan de

1578, Vocabvlario en lengva çapoteca, Pedro Charte and Antonio Ricardo, Mexico.

Domenici Davide

in press a, « Nuovi dati per una storia dei codici messicani della Biblioteca Apostolica Vaticana », Miscellanea Bibliothecae Apostolicae Vaticanae, 22.

in press b, « Telling material otherness: missionary gift records of Mexican objects in Early Modern Italy », in Elizabeth Horodowich and Lia Markey (eds.), The discovery of the New World in Early Modern Italy: encounters with the Americas in the 16th-17th century, Cambridge University Press, Cambridge. 
Domenici Davide

in preparation, « The Descrittione dell'India occidentale, an Italian 16th century source on Mesoamerican material culture », manuscript in preparation.

Domenici Davide and Laura Laurencich Minelli

2014, « Domingo de Betanzos' gifts to Pope Clement VII in 1532-1533: tracking the Early History of some Mexican Objects and Codices in Italy », Estudios de Cultura Náhuatl, 47, p. 169-210.

DuRÁn Diego

1995, Historia de las Indias de Nueva España e islas de Tierra Firme, Conaculta, Mexico. Duviols Jean-Paul

2006, Le miroir du nouveau monde. Images primitives de l'Amérique, Presses de l'université Paris-Sorbonne, Paris.

EMILIANi Andrea

2004, « Bendetto XIV, il collezionismo e il Museo pubblico », in Andrea Zanotti (ed.), Prospero Lambertini Pastore, Minerva, Bologna, p. 215-232.

FABIAN Johannes

1983, Time and the Other: how anthropology makes its object, Columbia University Press, New York.

FeinMan Gary M., Linda M. Nicholas and Lindsey C. BaKer

2010, « The missing femur at the Mitla Fortress and its implications », Antiquity, 84 (326), p. 1089-1101.

Fitzsimmons James L.

2009, Death and the Classic Maya Kings, University of Texas Press, Austin.

Foldi Ventura Irene and Laura Miani (eds.)

1987, Due carteggi inediti di Benedetto XIV, Analisi, Bologna.

GuALANDi Giorgio

1984, « La raccolta archeologica di Luigi Ferdinando Marsili e la "Stanza delle Antichità" dell'Istituto delle Scienze », in Cristiana Morigi Govi and Giuseppe Sassatelli (eds.), Dalla Stanza delle Antichità al Museo Civico, Grafis Edizioni, Bologna, p. 131-143.

GutiÉRrez Solana Nelly

1983, « Sobre un fémur con grabados perteneciente a la cultura mexica », Anales del Instituto de Investigaciones Estéticas, 52, p. 47-58.

Henare Amiria, Martin Holbraad and Sari Wastell (eds.)

2007, Thinking through things. Theorizing artefacts ethnographically, Routledge, London. Higelin Ponce de LeÓn Ricardo

2012, Symbolism and use of human femora by the Zapotecs in Oaxaca, México, during prehispanic times, M.A. thesis, Southern Illinois University, Carbondale.

2013, « El Omichicahuaztli: Veneración de Ancestros en la Región Este del Valle de Oaxaca durante el Clásico - Postclásico Prehispánico », paper presented at the Décimo Simposio Internacional de Estudios Oaxaqueños, Oaxaca (Mexico).

Higelin Ponce de León Ricardo and Gonzalo Sánchez Santiago

2014, «The Omichicahuaztli (scraper bone as musical instrument) in Southern Mesoamerica: a multiple-method approach to interpreting their use and 
significance among Prehispanic cultures of Oaxaca », paper presented at the

Society for American Archaeology 79th annual meeting, Austin (Texas).

Houston Stephen D.

2014, The life within. Classic Maya and the matter of permanence, Yale University Press, New Haven.

Houston Stephen, David Stuartand Karl Taube

2006, The memory of bones, body, being, and experience among the Classic Maya, University of Texas Press, Austin.

INCISA DELLA RoCChETTA Giovanni

1925, « Il Museo delle Curiosità del Cardinale Flavio Chigi Seniore », Roma, 3 (12), p. 539-544.

1966, « Il Museo delle Curiosità del Cardinale Flavio I Chigi », Archivio della Società Romana di Storia Patria, 89, p. 141-192.

JOYCE Arthur A.

2010, Mixtecs, Zapotecs, and Chatinos: ancient peoples of southern Mexico, WileyBlackwell, London.

Joyce Arthur A. and Marc Levine

2008, « Tututepec (Yucu Dzaa). Un imperio del Posclasico en la Mixteca de la Costa », Arqueologia Mexicana, 90, p. 44-47.

Joyce Arthur A., Andrew Workinger and Byron Hamann

2004, « Tututepec, un centro imperial del Posclasico en la Costa de Oaxaca », in Nelly Robles Garcia (ed.), Estructuras Politicas en el Oaxaca Antiguo. Memoria de la Tercera Mesa Redonda de Monte Alban, InAH, Mexico, p. 205-230.

Joyce Arthur A., Andrew Workinger, Byron Hamann and Marc N. Levine

2008, « The Archaeology and codical history of Tututepec », in Maarten E.R.G.N. Jansen and Laura N.K. van Broekhoven (eds.), Mixtec writing and society, Royal Netherlands Academy of Arts and Sciences, Amsterdam, p. 233-251.

KeAting Jessica and Lia MARKEY

2011, " "Indian” objects in Medici and Austrian-Habsburg inventories: a case-study of the sixteenth-century term », Journal of the History of Collections, 23 (2), p. 283-300.

KING Mark B.

1994, « Hearing the Echoes of verbal Art in Mixtec Writing », in Elizabeth Hill Boone and Walter D. Mignolo (eds.), Writing without words. Alternative literacies in Mesoamerica and the Andes, Duke University Press, Durham/London, p. 102-136.

KopytofF Igor

1986, « The cultural biography of things: commoditization as process », in Arjun Appadurai (ed.), The social life of things, Cambridge University Press, Cambridge, p. 64-91.

LAGUNAS Zahíd

2004, « El Uso Ritual del Cuerpo en el México Prehispánico », Arqueología Mexicana, 11 (65), p. 42-47.

LAURENCich Minelli Laura

1992, « Bologna e il Mondo Nuovo », in Laura Laurencich Minelli (ed.), Bologna e il Mondo Nuovo, Grafis Edizioni, Bologna, p. 9-23. 
LEMERY Nicholas

1721, Vollständiges Materialien-Lexicon, Leipzig.

LIND Michael and Javier URCID

2010, The Lords of Lambityeco: political evolution in the Valley of Oaxaca during the Xoo Phase, University Press of Colorado, Boulder.

LóPEz Austin Alfredo

1996, Cuerpo humano e ideología. Las concepciones de los antiguos nahuas, IIA/ UnAm, Mexico, 2 vols.

Lumholtz Carl and Aleš HrdLickA

1898, «Marked human bones from a prehistoric Tarasco Indian burial place in the state of Michoacan, Mexico », Bulletin of the American Museum of Natural History, X, p. 61-79.

Massajoli Pierleone and Mario Mattioni

1983, « Gli Zapotechi secondo un anonimo religioso italiano del Xvi secolo », L'Universo, 63 (4), p. 489-520.

Mazzetti Serafino

1840, Memorie storiche sopra l'Universita e l'Istituto delle Scienze di Bologna e sopra gli stabilimenti e i corpi scientifici alla medesima addetti, S. Tommaso d'Aquino, Bologna.

MCVICKER Donald

2005, « Notched human bones from Mesoamerica », Mesoamerican Voices, 2, p. 1-31. Medica Massimo

1992, « Gli “exotica” americani donati da Benedetto XIV. Una vicenda poco nota legata al patrimonio dell'Istituto delle Scienze », in Laura Laurencich Minelli (a cura di), Bologna e il Mondo Nuovo, Grafis Edizioni, Bologna, p. 37-43.

Miller Daniel (ed.)

2005, Materiality, Duke University Press, Durham.

Molina Alonso de

2008 [1571], Vocabulario en lengua castellana y mexicana, Editorial Porrúa, Mexico. Morigi Govi Cristiana

1984, «Il Museo Civico del 1871 », in Cristiana Morigi Govi and Giuseppe Sassatelli (eds.), Dalla Stanza delle Antichità al Museo Civico, Grafis Edizioni, Bologna, p. 259-267.

OSORIO ROMERo Ignacio

1993, La luz imaginaria: epistolario de Atanasio Kircher con los novohispanos, UnAM, Mexico.

PereIRA Gregory

2005, « The utilization of grooved human bones: a reanalysis of artificially modified human bones excavated by Carl Lumholtz at Zacapu, Michoacán, Mexico "), Latin American Antiquity, 16 (3), p. 293-312.

Pigorini Luigi

1885, « Gli antichi oggetti messicani incrostati di mosaico esistenti nel Museo Preistorico ed Etnografico di Roma », Atti della Reale Accademia dei Lincei. Serie 3: Memorie della Classe di Scienze Morali, Storiche e Filosofiche, 12, p. 3-10. 
Prodi Paolo and Maria Teresa FATTORI

2011, Le lettere di Benedetto XIV al Marchese Paolo Magnani, Herder Editrice Libraria, Roma.

Roulet Eric

2008, « Los Caciques de Coatlán frente al Cristianismo (Nueva España 1544-1547) », Asian Journal of Latin American Studies, 21 (1), p. 97-130.

SAHAGÚN Bernardino de

1982, Florentine Codex. General history of the things of New Spain, translation and notes by Arthur J.O. Anderson and Charles E. Dibble, University of Utah Press, Salt Lake City.

Sánchez Santiago Gonzalo and Ricardo Higelin Ponce de León

2014, «El quego xilla en la antigua Oaxaca: Una aproximación a los idiófonos de ludimiento », in Matthias Stöckli and Mark Howell (eds.), Flower World. Musical Archaeology of the Americas, vol. 3, Ekho Verlag, Berlin, p. 101-121.

SAVILLE Marshall H.

1922, Turquoise mosaic art in Ancient Mexico, Museum of the American Indian, New York. ScHIASSI Filippo

1814, Guida del forestiere al Museo delle antichità della regia Università di Bologna, Tipografia di Giuseppe Lucchesini, Bologna.

SELER Eduard

1992 [1898], « Ancient Mexican bone rattles », in Eduard Seler, Collected works in Mesoamerican linguistics and archaeology, vol. 3, Labyrinthos, Culver City, p. 62-73.

SimÉON Rémi

2006 [1885], Diccionario de la lengua náhuatl o mexicana, Siglo Veintiuno, Mexico.

SPOREs Ronald

1993, « Tututepec. A postclassic period Mixtec conquest state », Ancient Mesoamerica, 4, p. 167-174.

SPORES Ronald and Andrew BALKANSKY

2013, The Mixtecs of Oaxaca: ancient times to the present, University of Oklahoma Press, Norman.

STARR Frederick

1899, « Notched bones from Mexico », Proceedings of the Davenport Academy of Sciences, 7, p. 101-107.

STumpo Enrico

1980, « Flavio Chigi », in Alberto Maria Ghisalberti (ed.), Roberto Abbondanza (collab.) et al., Dizionario biografico degli italiani, vol. 24, Istituto della Enciclopedia Italiana, Roma, p. 747-751.

Thomas Nicholas

1991, Entangled objects. Exchange, material culture, and colonialism in the Pacific, Harvard University Press, Cambridge/London.

URCID Javier

2008, «El arte de pintar tumbas: sociedad e ideología zapotecas (400-800 d.C.) », in Beatríz De la Fuente (ed.), La Pintura Mural Prehispánica en México, t. IV, UnAm/IIAS, Mexico, p. 513-627. 
URCID Javier

2010, «El sacrificio humano en el suroeste de Mesoamérica », in Leonardo López Luján and Guilhem Olivier (eds.), El sacrificio humano en la tradición religiosa mesoamericana, InAH/Unam, Mexico, p. 115-168.

Velázquez Castro Adrián, Belém ZúÑiga Arellano and Norma Valentín Maldonado 2014, Identificación de las piezas de concha del Omichicauaztli del Museo Nazionale Preistorico Etnografico " Luigi Pigorini » de Roma, Project Report.

Von WinNING Hasso

1959, « A decorated bone rattle from Culhuacan, Mexico », American Antiquity, 25 (1), p. 86-93. 